\title{
Effects of ovarian follicle ablation on FSH, oestradiol and inhibin A concentrations and growth of other follicles in sheep
}

\author{
A. C. O. Evans ${ }^{1}$, J. D. Flynn ${ }^{1}$, P. Duffy², \\ P. G. Knight ${ }^{3}$ and M. P. Boland ${ }^{1}$ \\ ${ }^{1}$ Department of Animal Science and Production, and ${ }^{2}$ Lyons Research Farm, Conway \\ Institute for Biomolecular and Biomedical Research, University College Dublin, Belfield, \\ Dublin 4, Ireland; and ${ }^{3}$ School of Animal and Microbial Sciences, University of Reading, \\ Whiteknights, Reading, UK
}

\begin{abstract}
The aim of this study was to examine the effect of removal of the largest follicle or all visible follicles during the first follicle wave on subsequent follicular growth, steroid, inhibin $A$ and gonadotrophin secretion in sheep. On day 4.5 of a synchronized oestrous cycle, ewes $(n=18)$ were assigned to one of three groups which underwent either no treatment (control), ablation of the largest follicle (largest follicle aspirated and cauterized via laparotomy) or ablation of all follicles (all visible follicles ablated). Between day 0 and day 10 of the oestrous cycle, blood samples were collected every $8 \mathrm{~h}$ and ovaries were examined daily using transrectal ultrasonography. The lifespan of the second largest follicle (number of days $>3 \mathrm{~mm}$ in diameter) was longer $(6.7 \pm 0.9$ days; $P<0.05)$ and the maximum diameter tended to be greater $(4.8 \pm 0.3 \mathrm{~mm} ; P=0.07)$ in ewes in which the largest follicle was ablated than in the control ewes $(3.8 \pm 0.4$ days; $4.2 \pm 0.3 \mathrm{~mm}$ ). There was no difference in the day of emergence of the second follicular wave between groups (day $6.9 \pm 0.4)$. However, the peak of the transient increase in FSH
\end{abstract}

concentrations after ablation was earlier (day $5.67 \pm 0.15$; $P<0.05)$ in ewes in which all follicles were ablated than in control ewes (day $6.72 \pm 0.36$ ); the timing in ewes that had only the largest follicle ablated was intermediate (day $6.11 \pm 0.28$ ). Serum inhibin $A$ concentrations were about three-fold lower $(P<0.05)$ in both follicle ablation groups than in the control group. The numbers of follicles $2-3 \mathrm{~mm}$ in diameter during the first 3 days of the second follicular wave were greater in 'ablated ewes' (both groups had 2.6 \pm 0.2 follicles day $\left.{ }^{-1}\right)$ than in control ewes $\left(1.7 \pm 0.3\right.$ follicles day $\left.^{-1}\right)$. It is concluded that: (i) transient increases in FSH concentrations precede the emergence of follicle waves; (ii) ablation of all follicles on day 4.5 after oestrus advanced the timing of the next peak in FSH concentrations and the numbers of small follicles associated with the development of the second follicular wave; and (iii) ablation of the largest follicle resulted in an increase in the lifespan of the second largest follicle, indicating a regulatory role of large dominant follicles over smaller subordinate follicles.

\section{Introduction}

Waves of follicular growth and a dominant follicle are found in cattle (Fortune, 1994; Ginther et al., 1996; Roche et al., 1998) and, despite early controversy, it appears that there are also waves of follicular growth in sheep (Noel et al., 1993; Ginther et al., 1995; Leyva et al., 1998; Evans et al., 2000), although the occurrence of dominance remains to be established. In cattle, a wave of follicular growth involves the synchronous growth $(>4-8 \mathrm{~mm}$ in diameter) of a cohort of follicles from the follicle reserve, followed by the continued development of one follicle (dominant follicle) and the atresia of all other follicles from the original cohort. Emergence of a new wave occurs after the dominant follicle from the previous wave undergoes atresia (Ginther et al., 1996). A wave-like pattern of follicle growth similar to that in cattle has been described in sheep; however, the diameter of follicles in sheep is smaller than in

Email: alex.evans@ucd.ie cattle: emergence occurs at a follicle diameter of $2 \mathrm{~mm}$ and the maximum diameter achieved by the ovulatory follicle is 6-7 mm (Ginther et al., 1995; Evans et al., 2000).

The existence of dominance in sheep is still unresolved. Some authors have reported that a weak form of dominance may exist on the basis of the observation that the largest follicle may delay or prevent the development of other follicles (Ravindra et al., 1994; Ginther et al., 1995; Rubianes et al., 1997). Evans et al. (2000) argued for the occurrence of dominance in sheep on the basis of a hierarchy in terms of diameter and oestradiol concentration of the largest follicle, and an apparent relationship between the demise of the largest follicle and the emergence of the subsequent wave.

The mechanism involved in the selection of the dominant follicle is unclear. In cattle, it appears that the future dominant follicle is capable of switching its dependency from FSH secretion to $\mathrm{LH}$ and, therefore, can survive in an environment of decreasing FSH concentrations (Ginther et al., 1996; Webb et al., 1999). However, there is 
also evidence that the dominant follicle inhibits the growth of other follicles. In cattle, removal of the dominant follicle on day 3 of the oestrous cycle resulted in delayed regression of the largest subordinate follicle, early emergence of the second wave of follicular growth and an increase in the proportion of animals with three rather than two waves per cycle (Ko et al., 1991; Adams et al., 1993). The emergence of a new wave has been associated with a transient increase in FSH concentrations in cattle (Adams et al., 1992; Evans et al., 1997) and sheep (Souza et al., 1998; Bister et al., 1999; Gibbons et al., 1999; Bartlewski et al., 2000). Advancing the timing of the FSH increase and emergence of a new wave of follicles by ablation of the dominant follicle and postponement of the FSH increase and emergence of a new wave of follicles by i.v. treatment with follicular fluid demonstrates that the dominant follicle actively suppresses the growth of other follicles in cattle (Adams et al., 1992). In sheep, the influence of the largest follicle on the increase in $\mathrm{FSH}$ concentrations that triggers the emergence of the subsequent wave has yet to be established.

The aim of the present study was to examine the influence of removal of the largest follicle or all visible follicles on subsequent follicular growth, oestradiol, FSH and inhibin A concentrations, and, hence, to determine whether dominance occurs in sheep, as in cattle. Follicles were removed by ablating (via laparotomy and cauterization) either the largest follicle or all visible follicles on day 4.5 of the oestrous cycle.

\section{Materials and Methods}

\section{Animals and treatments}

All procedures were in accordance with the Cruelty to Animals Act, 1876 (European Community Directive 86/609/EC) licensed by the Department of Health and Children, Ireland. During December, nine Suffolk-cross and nine Texel-cross maiden ewe lambs $(40 \pm 0.35 \mathrm{~kg})$ were maintained at pasture $\left(53018^{\prime} \mathrm{N}\right)$ where they had access to water and hay and $0.4 \mathrm{~kg}$ concentrates $(19 \%(\mathrm{w} / \mathrm{w})$ crude protein) per day. The oestrous cycles of the ewes were presynchronized using a 14 day intravaginal progestagen sponge (60 mg medroxyprogesterone acetate; Veramix, Upjohn Cranley). Follicular growth patterns were studied daily (at 08:00 h) from the day of sponge removal until day 10 of the subsequent oestrous cycle by transrectal ultrasonography using a real time B mode scanner (Dynamic Imaging Concept MLV) with a $7.5 \mathrm{MHz}$ linear array transducer (Evans et al., 2000). Oestrus was detected using a raddled vasectomized ram.

The day of follicle emergence was traced retrospectively as the day on which follicles were first recorded with a diameter of 2-3 mm. The lifespan of a follicle was defined as the number of days on which an identified follicle was detected with a diameter of $\geqslant 3 \mathrm{~mm}$.

On day 4.5 of the oestrous cycle (between 15:00 $\mathrm{h}$ and 18:00 h) the ewes were assigned randomly to one of three treatments: (i) control; (ii) ablation of the largest follicle; or (iii) ablation of all visible follicles. Ewes in all groups were sedated (400 $\mu$ l i.m.; Rompun ${ }^{\circledR}$; Bayer Plc, Bury St Edmunds) and follicles were ablated under local anaesthesia $(20 \mathrm{ml}$ s.c.; lignocaine plus adrenaline; Norbrook Laboratories Ireland Ltd, Monaghan) via mid-ventral laparotomy (control ewes were sedated only). Follicles were measured using callipers; follicular fluid was aspirated using a 25G needle and the collapsed follicle was cauterized completely (Ko et al., 1991).

\section{Blood collection and hormone analysis}

Blood samples $(7 \mathrm{ml})$ were collected three times a day (at 07:00, 15:00 and 23:00 h) from day 0 to day 10 of the oestrous cycle by jugular venepuncture. The samples were stored at $4^{\circ} \mathrm{C}$ for $24 \mathrm{~h}$ and centrifuged at $1500 \mathrm{~g}$ for $20 \mathrm{~min}$ at $4^{\circ} \mathrm{C}$. The serum was decanted and stored at $-20^{\circ} \mathrm{C}$ until assayed for oestradiol, FSH and inhibin A concentrations. Follicular fluid samples collected from follicles that were ablated were centrifuged at $1000 \mathrm{~g}$ for $1 \mathrm{~min}$, decanted and stored at $-20^{\circ} \mathrm{C}$ until assayed for oestradiol and inhibin A concentrations.

\section{Radioimmunoassays}

Oestradiol concentrations in serum samples collected three times a day were assayed by validated radioimmunoassay (Prendiville et al., 1995). The sensitivity of the assay was 0.03 pg per tube. The intra- and interassay coefficients of variation for reference samples with average concentrations of $1.78,2.76$ and $5.37 \mathrm{pg}$ oestradiol $\mathrm{ml}^{-1}$ included in each assay were 5.8 and $7.9 \%, 6.0$ and $7.0 \%$, and 6.6 and $9.9 \%$, respectively.

FSH concentrations were measured in all serum samples using a validated radioimmunoassay (Crowe et al., 1997), which included an anti-ovine antibody (NIDDK anti-oFSH) but with the modification of ovine standards (USDA-oFSHSIAFP-RP-2). The sensitivity of the assay was $0.06 \mathrm{ng} \mathrm{ml}^{-1}$ (defined as the least amount of unlabelled FSH tested that could displace iodinated FSH from the first antibody; $P<0.05, t$ test). Intra-assay coefficients of variation were 10,10 and $3 \%$ for samples containing $0.23,0.87$ and $2.87 \mathrm{ng} \mathrm{ml}^{-1}$, respectively. Interassay $(n=2)$ coefficients of variation for the same samples were 16, 9 and $12 \%$, respectively.

Inhibin A concentrations were measured in follicular fluid samples (diluted 1:25000) and in serum samples collected in the $12 \mathrm{~h}$ (two samples) before surgery and in the $48 \mathrm{~h}$ (six samples) after surgery using a modified version (Bleach et al., 2001) of a two-site ELISA (Knight et al., 1998). Sensitivity of the assay was $15 \mathrm{pg} \mathrm{ml}^{-1}$ and intra- and interassay coefficients of variation were 10.3 and $13.4 \%$, respectively.

\section{Statistical analysis}

Data were analysed using ANOVA or paired $t$ test and multiple comparisons were made by the method of least significant difference. The changes in FSH, oestradiol and 
Table 1. Characteristics of follicular growth in waves 1 and 2 in control ewes (no treatment), ewes in which the largest follicle was ablated and ewes in which all visible follicles were ablated on day 4.5 after oestrus

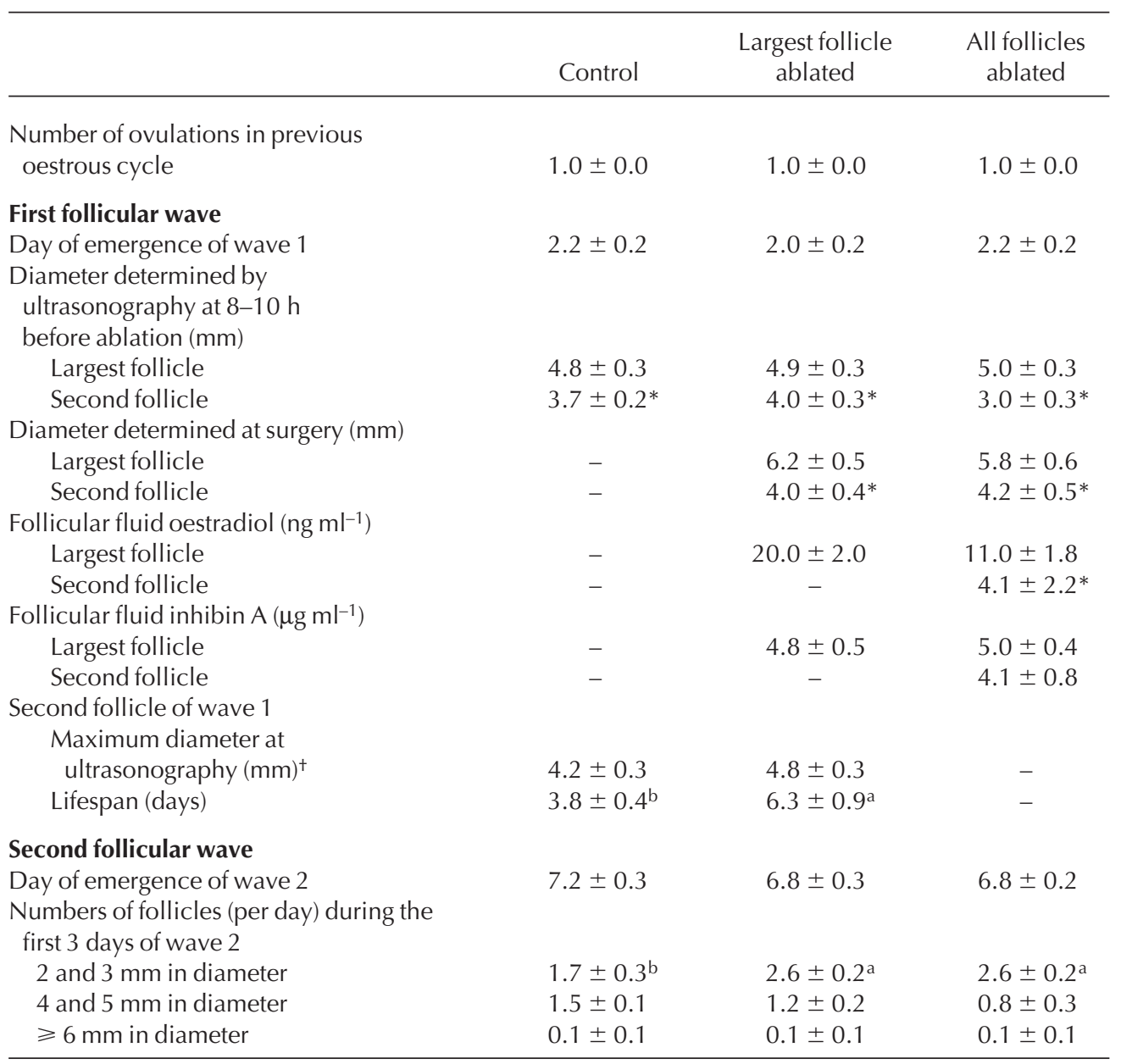

Values are mean $\pm \operatorname{SEM}(n=6)$.

*Indicates a lower value $(P<0.05)$ for the second largest compared with the largest follicle within a treatment (column).

abValues within a row with no common superscript are significantly different $(P<0.05)$.

${ }^{+}$Difference between treatments tends towards significance $(P=0.07)$.

inhibin A concentrations before and at about $24 \mathrm{~h}$ after surgery were calculated using the mean of samples taken over the $4-12 \mathrm{~h}$ interval before surgery (samples from days 4.00 and 4.33 of the oestrous cycle) and the 20-28 $\mathrm{h}$ interval after surgery (samples from days 5.33 and 5.67 of the oestrous cycle). These times were chosen as optimal to reflect changes in hormone concentrations caused by follicle ablation.

\section{Results}

All of the ewes ovulated a single follicle at the end of the synchronized oestrous cycle as determined by ultrasonography and by counting corpora lutea in those ewes that underwent laparotomy. The dynamics of growth of the two largest follicles per wave are shown (Fig. 1). The day of emergence of the first follicular wave was similar in all groups (combined mean $2.1 \pm 0.1$ days after oestrus; Table 1). On day 4 in all groups, the largest follicle had a significantly greater $(P<0.05)$ diameter than did the second largest follicle, as measured initially by ultrasonography and confirmed at surgery in ewes that had follicles ablated (Table 1). The concentration of oestradiol in follicular fluid was greater $(P<0.05)$ in the largest follicle than in the second largest follicle in ewes in which all follicles were ablated, but there was no difference in the follicular fluid concentration of inhibin A between these follicles (Table 1). The lifespan of the second largest follicle (number of days that the diameter was $\geqslant 3 \mathrm{~mm}$ ) was on average 2.5 days longer $(P<0.05)$ and tended $(P=0.07)$ to have a greater maximum diameter in ewes in which the largest follicle was ablated than in control ewes (Table 1). 


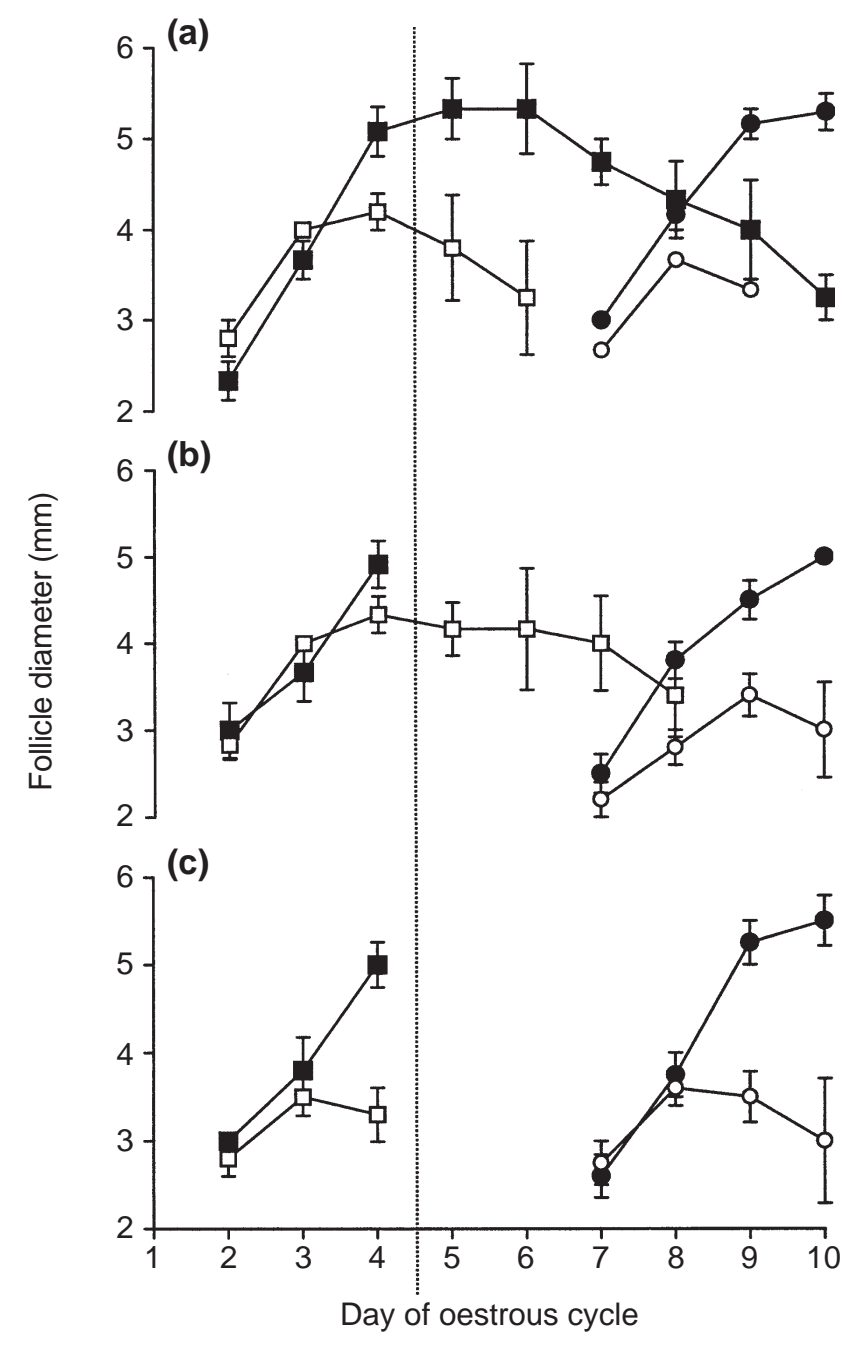

Fig. 1. Diameters of the largest and second largest follicles in the first and second follicular waves measured using transrectal ultrasonography. (a) Control ewes (sedation only). (b) Ewes in which the largest follicle was ablated on day 4.5 of the oestrous cycle. (c) Ewes in which all visible follicles were ablated on day 4.5 of the oestrous cycle. (ם) Largest follicle, first wave; (-) largest follicle, second wave; $(\square)$ second largest follicle, first wave; $(\bigcirc)$ second largest follicle, second wave. Values are mean $\pm \operatorname{SEM}(n=6$ per group). Data were aligned to the mean day of follicle wave emergence. Vertical dotted line indicates the time of follicle ablation.

The second follicular wave emerged at a similar time in the three groups (combined mean $6.9 \pm 0.2$ days after oestrus; Table 1$)$. There were a higher $(P<0.05)$ number of small follicles $(2-3 \mathrm{~mm}$ in diameter) during the first 3 days of the second follicular wave in ewes that had the largest or all follicles ablated than in the control ewes (Table 1). There was a tendency $(P=0.07)$ for a difference among groups for the number of medium-sized follicles (4-5 $\mathrm{mm}$ in diameter) during the first 3 days of the second wave, with the lowest number in ewes that had all follicles ablated $(0.8 \pm 0.3)$ and the highest number in control ewes $(1.5 \pm 0.1$; Table 1$)$. There were no differences among groups in the numbers of large follicles (> $6 \mathrm{~mm}$ in diameter) present during the first 3 days of the second follicular wave (Table 1).

The pattern of circulating hormone concentrations is shown (Fig. 2). Oestradiol concentrations peaked before surgery at a similar time and concentration in all three groups (combined means: $3.7 \pm 0.2$ days and $1.91 \pm 0.17 \mathrm{pg} \mathrm{ml}^{-1}$; Table 2). Similarly, FSH concentrations reached nadir concentrations at a similar time and concentration in all three groups (combined means: day $3.8 \pm 0.2$ and $1.0 \pm 0.13 \mathrm{ng}$ $\mathrm{ml}^{-1}$; Table 2). Concentrations of oestradiol and inhibin A decreased and FSH concentrations increased from $8 \mathrm{~h}$ before to $24 \mathrm{~h}$ after surgery in all groups of ewes $(P<0.05$; Table 2). Concentrations of each of these hormones were similar among groups before surgery but FSH concentrations were higher $(P<0.05)$ and inhibin A concentrations were lower $(P<0.05)$ at $24 \mathrm{~h}$ after surgery in the two groups of ewes in which follicles were ablated compared with control ewes (Table 2). The day of the oestrous cycle on which the circulating oestradiol concentrations reached a nadir was not significantly different among the groups, but was earliest in ewes in which all follicles were ablated and latest in the control ewes (Table 2). FSH reached peak concentrations sooner $(P<0.05)$ after surgery in ewes in which all follicles were ablated than in control ewes, and was intermediate in ewes in which only the dominant follicle was ablated (Table 2). In addition, there was a tendency $(P=0.06)$ for a difference among groups for the peak concentration of $\mathrm{FSH}$, being lowest in control ewes and highest in ewes in which the largest follicle was ablated (Table 2).

When comparing the timing of peak and nadir hormone concentrations between oestradiol and FSH (within a treatment group), the day of the oestrous cycle on which oestradiol concentrations reached a peak and FSH concentrations reached a nadir was not different within any group (combined means: day $3.7 \pm 0.2$ of the oestrous cycle; Table 2 ). The days on which FSH concentrations reached a peak and oestradiol concentrations reached a nadir were also not different between control ewes and ewes that had the largest follicle ablated, but was later in ewes in which all follicles were ablated (see Table 2).

\section{Discussion}

The results of the present study indicate that removal of the largest follicle results in continued survival of the second largest follicle, implying that the largest follicle has a role in regulation of the lifespan of other follicles. In addition, removal of the largest, or all follicles, resulted in a rapid decrease in inhibin A concentrations and an increase in FSH concentrations, leading to an increase in the numbers of small follicles in the subsequent follicular wave.

The emergence of follicular waves was associated with transient increases in $\mathrm{FSH}$ concentrations in agreement with previous studies (Souza et al., 1998; Bister et al., 1999; Gibbons et al., 1999; Bartlewski et al., 2000). It is accepted that FSH secretion is controlled by both oestradiol and 
inhibin negative feedback (Mann et al., 1992; Knight et al., 1998); however, the relative roles of each are not clear. In the present study, circulating concentrations of oestradiol peaked in all groups (at about day 3.7) before surgery (on day 4.5). Oestradiol concentrations were decreasing at about the time of surgery in all groups but the results indicated that the more follicles that were ablated, the earlier oestradiol reached nadir concentrations. Inhibin A concentrations decreased from before surgery to about $85 \%$ at $24 \mathrm{~h}$ after surgery in control ewes but decreased to $38 \%$ in ewes that had the largest follicle ablated and to $29 \%$ in ewes that had all follicles ablated. This finding is in agreement with another study in which all follicles were ablated and immunoreactive inhibin concentrations in the ovarian vein decreased to $65 \%$ from before to 10 min after ablation (Findlay et al., 1990). The fluctuations in FSH concentrations, although advanced in the two groups of ewes in which follicles were ablated, reached similar concentrations in all groups. The temporal relationship between the decrease in inhibin A concentrations and the increase in $\mathrm{FSH}$ concentrations observed in ewes in which follicles were ablated indicates that inhibin A may be an important regulator of FSH secretion in sheep. However, peak FSH concentrations were not different among groups and small changes in inhibin A concentrations in control ewes resulted in a similar pattern of fluctuation in FSH concentrations to that of ewes in which a large decrease in inhibin A concentration was observed (ablated ewes). If inhibins were the main regulators of FSH concentrations, a greater increase after follicle ablation (and inhibin removal) would have been expected. Hence, changes in oestradiol concentrations may be significant regulators of FSH concentrations in ewes, even when these changes are small and not detectable. An alternative suggestion is that the pituitary may be maximally responsive to small changes in inhibin or steroid (possibly including androgens) concentrations. Once a small threshold change occurs (as in inhibin A concentrations in the control ewes), a maximum response is elicited that cannot be increased by a larger change in negative feedback (as in the large changes in inhibin A concentrations in the ewes in which follicles were ablated). In cattle, it has been suggested that inhibins regulate the background $\mathrm{FSH}$ secretion and that cyclic changes in oestradiol drive daily cyclic changes in FSH (Glencross et al., 1994); however, a role for inhibin A in controlling cyclic changes in FSH concentrations has been proposed (Bleach et al., 2001). Further experiments are needed to determine accurately the relative roles of oestradiol and inhibins in the regulation of $\mathrm{FSH}$ concentrations during the luteal phase of ewes. It should also be noted that inhibins have a local regulatory function in the ovary (Findlay et al., 2000; Campbell and Baird, 2001; Knight and Glister, 2001).

With hindsight, the optimal time for surgery would have been earlier than day 4.5 as was performed in this study. Day 4.5 after oestrus was selected for surgery as it was the earliest time at which the identity of the largest follicle could be predicted accurately using ultrasonography (Evans

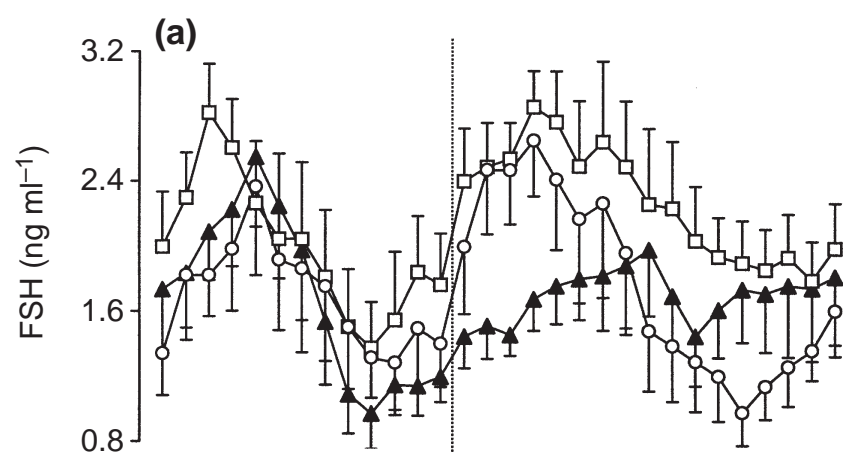

(b)
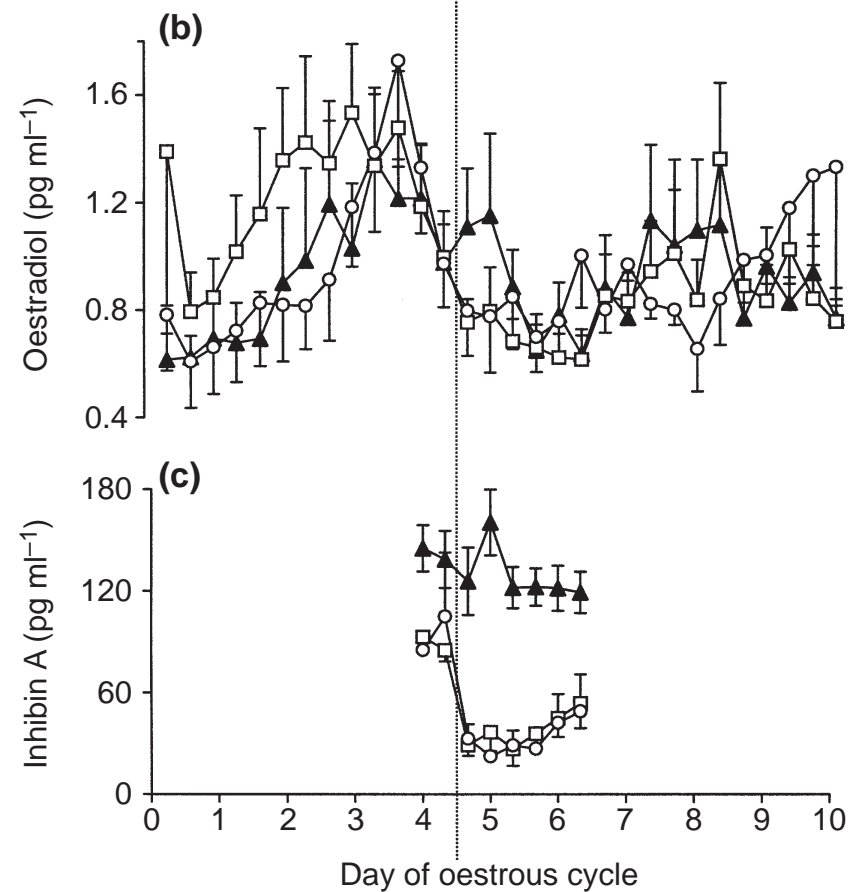

Fig. 2. (a) $\mathrm{FSH}$, (b) oestradiol and (c) inhibin A concentrations in control ewes ( $\boldsymbol{\Delta}$; sedation only), ewes in which the largest follicle was ablated ( $\square$ : largest follicle cauterized on day 4.5 after oestrus) and ewes in which all visible follicles were ablated $(\bigcirc$ : all visible follicles cauterized on day 4.5 after oestrus). FSH concentrations were aligned to the mean day of emergence of the first follicular wave and from two samples before surgery. Oestradiol and inhibin A concentrations were aligned (forwards and backwards) to the time of surgery. Values are mean $\pm \operatorname{SEM}(n=6)$. Vertical dotted line indicates the time of follicle ablation. Some error values were small and bars are contained within the plotted symbol.

et al., 2000). If oestradiol concentrations had still been increasing, and FSH concentrations had been decreasing at the time of surgery, the changes brought about by follicle ablation (such as the timing of nadir oestradiol concentrations and peak FSH concentrations) would have been expected to be more marked. Nevertheless, significant differences in oestradiol and FSH concentrations among groups are in agreement with the findings of other studies (Findlay et al., 1990; Souza et al., 1998) that follicle products regulate FSH concentrations and that the largest follicle has the most significant regulatory role. 
Table 2. Characteristics of plasma oestradiol, FSH and inhibin A concentrations in control ewes (no treatment), ewes in which the largest follicle was ablated and ewes in which all visible follicles were ablated on day 4.5 after oestrus

\begin{tabular}{|c|c|c|c|}
\hline & Control & $\begin{array}{l}\text { Largest follicle } \\
\text { ablated }\end{array}$ & $\begin{array}{c}\text { All follicles } \\
\text { ablated }\end{array}$ \\
\hline \multicolumn{4}{|l|}{ Peak oestradiol } \\
\hline Day of oestrous cycle & $3.82 \pm 0.37$ & $3.38 \pm 0.27$ & $3.78 \pm 0.11$ \\
\hline Concentration $\left(\mathrm{pg} \mathrm{ml} \mathrm{m}^{-1}\right)$ & $1.8 \pm 0.2$ & $1.8 \pm 0.3$ & $2.1 \pm 0.3$ \\
\hline \multicolumn{4}{|l|}{ Nadir FSH } \\
\hline Day of oestrous cycle & $4.11 \pm 0.42$ & $3.33 \pm 0.34$ & $3.83 \pm 0.21$ \\
\hline Concentration $\left(\mathrm{ng} \mathrm{ml}^{-1}\right)$ & $0.90 \pm 0.19$ & $1.08 \pm 0.22$ & $1.14 \pm 0.27$ \\
\hline \multicolumn{4}{|l|}{ Surgery } \\
\hline Day of oestrous cycle & 4.5 & 4.5 & 4.5 \\
\hline \multicolumn{4}{|l|}{ Hormone concentration } \\
\hline \multicolumn{4}{|l|}{$\mathrm{FSH}\left(\mathrm{ng} \mathrm{ml}^{-1}\right)$} \\
\hline Before ablation & $1.17 \pm 0.17^{*}$ & $1.80 \pm 0.33^{*}$ & $1.45 \pm 0.32 *$ \\
\hline After ablation & $1.56 \pm 0.15^{b}$ & $2.70 \pm 0.21^{\mathrm{a}}$ & $2.56 \pm 0.33^{a}$ \\
\hline \multicolumn{4}{|l|}{ Oestradiol (pg ml-1) } \\
\hline Before ablation & $1.1 \pm 0.2^{*}$ & $1.1 \pm 0.2^{*}$ & $1.2 \pm 0.2^{*}$ \\
\hline After ablation & $0.8 \pm 0.1$ & $0.7 \pm 0.1$ & $0.8 \pm 0.2$ \\
\hline \multicolumn{4}{|l|}{ Inhibin A (pg ml-1) } \\
\hline Before ablation & $142 \pm 15^{*}$ & $89 \pm 4^{*}$ & $95 \pm 22 *$ \\
\hline After ablation & $122 \pm 11^{\mathrm{a}}$ & $34 \pm 10^{b}$ & $28 \pm 6^{b}$ \\
\hline \multicolumn{4}{|l|}{ Nadir oestradiol } \\
\hline Day of oestrous cycle $e^{\ddagger}$ & $6.00 \pm 0.30$ & $5.71 \pm 0.24$ & $5.00 \pm 0.19$ \\
\hline Concentration $\left(p g \mathrm{ml}^{-1}\right.$ ) & $0.5 \pm 0.1$ & $0.5 \pm 0.1$ & $0.6 \pm 0.1$ \\
\hline \multicolumn{4}{|l|}{ Peak FSH } \\
\hline Day of oestrous cycle & $6.72 \pm 0.36^{a}$ & $6.11 \pm 0.28^{\mathrm{ab}}$ & $5.67 \pm 0.15^{b}$ \\
\hline Concentration $\left(\mathrm{ng} \mathrm{ml}^{-1}\right)^{\ddagger}$ & $2.23 \pm 0.36$ & $3.46 \pm 0.21$ & $2.83 \pm 0.42$ \\
\hline
\end{tabular}

Values are mean $\pm \operatorname{SEM}(n=6)$

*Indicates a difference $(P<0.05)$ between before ablation and after ablation values, within a hormone

+Hormone concentrations before and after ablation are the mean of two samples collected before (days 4.00 and 4.33 ) and $24 \mathrm{~h}$ after (days 5.33 and 5.67) ablation

${ }^{\ddagger}$ Difference among treatments tends towards significance $(P \leqslant 0.10)$.

ab Within rows, values with no common superscript are significantly different $(P<0.05)$.

Our findings are similar to those in cattle in which removal of the dominant or largest follicle resulted in delayed regression and larger diameter of the second largest follicle (Ko et al., 1991; Adams et al., 1993). New wave emergence occurred at a similar time in treated ewes and control ewes in the present study, but in cattle, follicle cauterization leads to the advancement of emergence of a new follicle wave. The failure to hasten new wave emergence in the ewes in the present study could be related to the timing of follicle ablation. At surgery, circulating concentrations of oestradiol were decreasing and $\mathrm{FSH}$ concentrations were increasing, and the mechanism to initiate new wave emergence had possibly already been initiated in all groups. However, ablation did increase FSH concentrations and stimulate the growth of more small follicles than in control ewes. In agreement with work in cattle (Evans et al., 1997), there was a temporal and negative relationship between the timing of peak and nadir oestradiol and FSH concentrations. In agreement with earlier studies, the follicular fluid samples indicated that the dominant follicle was the main source of oestradiol (Bjersing et al., 1972; Carson et al., 1981).

The increased lifespan of the second largest follicle in the ewes in which the largest follicle was ablated compared with the control ewes indicates that a form of dominance exists in mono-ovulatory sheep. All ewes in the experiment had ovulated a single follicle at the end of the previous cycle (Evans et al., 2000). The hierarchy of follicles in terms of diameter and oestradiol concentration in follicular fluid also supports the idea of dominance in sheep in agreement with other reports (Bjersing et al., 1972; Carson et al., 1981; Evans et al., 2000). The presence of a dominant follicle in cattle is associated with suppression of the number of follicles (Ginther et al., 1989). The increased number of small follicles (2-3 $\mathrm{mm}$ in diameter) observed in ewes in which the largest or all follicles were ablated provides further evidence for the occurrence of dominance in sheep. Hence, it appears that the largest or dominant follicle encourages the regression of other, subordinate follicles. How the dominant follicle influences the lifespan of the 
subordinate follicles is unclear but the effect is either indirect via the gonadotrophins or via an as yet undescribed local direct mechanism. Other data suggest that clear dominance does not occur in sheep. New follicle waves have been shown to emerge in the presence of large follicles from a previous wave (Flynn et al., 2000) and in some cases ovulated (Bartlewski et al., 1999) and new follicle waves emerged in the presence of steroidogenically active follicles from a previous wave in anoestrous ewes (Evans et al., 2001). Therefore, the occurrence of dominance may be reliant on a number of factors including breed of ewe, stage of reproductive cycle and time of year.

In conclusion, the emergence of new waves of follicular growth was associated with transient increases in $\mathrm{FSH}$ concentrations and these fluctuations in FSH concentrations appear to be regulated by follicle products (oestradiol and inhibin A). In addition, the largest follicle appears to regulate the growth of other follicles. The demise of the largest follicle increased the lifespan of the second largest follicle and resulted in an increase in the numbers of follicles in the subsequent follicular wave, indicating that ovarian follicle dominance occurs during the luteal phase of sheep.

The authors would like to thank N. Hynes, G. Claffey and S. Feist for assistance with hormone assays, T. Harte for overall care and provision of the animals, A. F. Parlow (NIDDK National Hormone \& Pituitary Programme) for the provision of reagents for the FSH assay and N.P. Groome (Oxford Brooks University) for inhibin assay reagents. This work was partly funded by a President's Research Award to A. Evans and a BBSRC grant (No SO5760) to P. Knight.

\section{References}

Adams GP, Matteri RL, Kastelic JP, Ko JCH and Ginther OJ (1992) Association between surges of follicle-stimulating hormone and the emergence of follicular waves in heifers Journal of Reproduction and Fertility 94 177-188

Adams GP, Kot K, Smith CA and Ginther OJ (1993) Effect of the dominant follicle on regression of its subordinates in heifers Canadian Journal of Animal Science 73 267-275

Bartlewski PM, Beard AP, Cook SJ, Chandolia RK, Honaramooz A and Rawlings NC (1999) Ovarian antral follicular dynamics and their relationships with endocrine variables throughout the oestrous cycle in breeds of sheep differing in prolificacy Journal of Reproduction and Fertility 115 111-124

Bartlewski PM, Beard AP and Rawlings NC (2000) An ultrasound-aided study of temporal relationships between the patterns of $\mathrm{LH} / \mathrm{FSH}$ secretion, development of ovulatory-sized antral follicles and formation of corpora lutea in ewes Theriogenology $\mathbf{5 4} 229-245$

Bister JL, Noel B, Perrad B, Mandiki SN, Mbayahaga J and Paquay R (1999) Control of ovarian follicle activity in the ewe Domestic Animal Endocrinology 17 315-328

Bjersing L, Hy MF, Kann G, Moor RM, Naftolin F, Scaramuzzi RJ, Short RV and Younglai EV (1972) Changes in gonadotrophins, ovarian steroids and follicular morphology in sheep at oestrus Journal of Endocrinology 52 465-479

Bleach EC, Glencross RG, Feist SA, Groome NP and Knight PG (2001) Plasma inhibin A in heifers: relationship with follicle dynamics, gonadotropins, and steroids during the estrous cycle and after treatment with bovine follicular fluid Biology of Reproduction 64 743-752

Campbell BK and Baird DT (2001) Inhibin A is a follicle stimulating hormone-responsive marker of granulosa cell differentiation, which has both autocrine and paracrine actions in sheep Journal of Endocrinology $169333-345$

Carson RS, Findlay JK, Clarke IJ and Burger HG (1981) Estradiol, testosterone and androstenedione in ovine follicular fluid during growth and atresia of ovarian follicles Biology of Reproduction 24 105-113

Crowe MA, Padmanabhan V, Hynes N, Sunderland SJ, Enright WJ, Beitins IZ and Roche JF (1997) Validation of a sensitive radioimmunoassay to measure serum follicle-stimulating hormone in cattle: correlation with biological activity Animal Reproduction Science 48 123-136

Evans ACO, Komar CM, Wandji S-A and Fortune JE (1997) Changes in androgen secretion and luteinizing hormone pulse amplitude are associated with the recruitment and growth of ovarian follicles during the luteal phase of the bovine estrous cycle Biology of Reproduction $\mathbf{5 7}$ 394-401

Evans ACO, Duffy P, Hynes N and Boland MP (2000) Waves of follicle development during the estrous cycle in sheep Theriogenology $\mathbf{5 3}$ 699-715

Evans ACO, Duffy P, Quinn KM, Knight PG and Boland MP (2001) Follicular waves are associated with transient fluctuations in FSH but not oestradiol or inhibin-A concentrations in anoestrous ewes Animal Science 72 547-554

Findlay JK, Clarke IJ and Robertson DM (1990) Inhibin concentrations in ovarian and jugular venous plasma and the relationship of inhibin with follicle-stimulating hormone and luteinizing hormone during the ovine estrous cycle Endocrinology 126 528-535

Findlay JK, Drummond AE, Britt KL, Dyson M, Wreford NG, Robertson DM, Groome NP, Jones ME and Simpson ER (2000) The roles of activins, inhibins and estrogen in early committed follicles Molecular and Cellular Endocrinology 163 81-87

Flynn JD, Duffy P, Boland MP and Evans ACO (2000) Progestagen synchronisation in the absence of a corpus luteum results in the ovulation of a persistent follicle in cyclic ewe lambs Animal Reproduction Science 62 285-296

Fortune JE (1994) Ovarian follicular growth and development in mammals Biology of Reproduction $\mathbf{5 0} 225-232$

Gibbons JR, Kot K, Thomas DL, Wiltbank MC and Ginther OJ (1999) Follicular and FSH dynamics in ewes with a history of high and low ovulation rates Theriogenology 52 1005-1020

Ginther OJ, Kastelic JP and Knopf L (1989) Composition and characteristics of follicular waves during the bovine estrous cycle Animal Reproduction Science 20 187-200

Ginther OJ, Kot K and Wiltbank MC (1995) Associations between emergence of follicular waves and fluctuations in FSH concentrations during the estrous cycle in ewes Theriogenology 43 689-703

Ginther OJ, Wiltbank MC, Fricke PM, Gibbons JR and Kot K (1996) Selection of the dominant follicle in cattle Biology of Reproduction $\mathbf{5 5}$ 1187-1194

Glencross RG, Bleach ECL, Wood SC and Knight PG (1994) Active immunization of heifers against inhibin: effect of plasma concentrations of gonadotrophins, steroids and ovarian follicular dynamics during prostaglandin-synchronized cycles Journal of Reproduction and Fertility 100 599-605

Knight PG and Glister C (2001) Potential local regulatory functions of inhibins, activins and follistatin in the ovary Reproduction 121 503-512

Knight PG, Feist SA, Tannetta DS, Bleach EC, Fowler PA, $\mathrm{O}^{\prime}$ Brien $\mathrm{M}$ and Groome NP (1998) Measurement of inhibin-A ( $\alpha \beta A$ dimer) during the oestrous cycle, after manipulation of ovarian activity and during pregnancy in ewes Journal of Reproduction and Fertility 113 159-166

Ko JCH, Kastelic JP, Del Campo MR and Ginther OJ (1991) Effects of a dominant follicle on ovarian follicular dynamics during the estrous cycle in heifers Journal of Reproduction and Fertility 91 511-520

Leyva V, Buckrell BC and Walton JS (1998) Regulation of follicular activity and ovulation in ewes by exogenous progesterone Theriogenology $\mathbf{5 0}$ 395-416

Mann GE, Campbell BK, McNeilly AS and Baird DT (1992) The role of inhibin and oestradiol in the control of FSH secretion in the sheep Journal of Endocrinology 133 381-391

Noel B, Bister JL and Paquay R (1993) Ovarian follicular dynamics in 
Suffolk ewes at different periods of the year Journal of Reproduction and Fertility 99 695-700

Prendiville DJ, Enright WJ, Crowe MA, Finnerty M, Hynes N and Roche JF (1995) Immunization of heifers against gonadotropin-releasing hormone: antibody titers, ovarian function, body growth, and carcass characteristics Journal of Animal Science 73 2382-2389

Ravindra JP, Rawlings NC, Evans ACO and Adams GP (1994) Ultrasonographic study of ovarian follicular dynamics in ewes during the oestrous cycle Journal of Reproduction and Fertility 101 501-509

Roche JF, Mihm M, Diskin MG and Ireland JJ (1998) A review of regulation of follicle growth in cattle Journal of Animal Science 76 (Supplement 3) 16-29

Rubianes E, Ungerfeld R, Vinoles C, Rivero A and Adams GP (1997) Ovarian response to gonadotropin treatment initiated relative to wave emergence in ultrasonographically monitered ewes Theriogenology $\mathbf{4 7}$ 1479-1488
Souza CJ, Campbell BK and Baird DT (1998) Follicular waves and concentrations of steroids and inhibin A in ovarian venous blood during the luteal phase of the oestrous cycle in ewes with an ovarian autotransplant Journal of Endocrinology 156 563-572

Webb R, Campbell BK, Garverick HA, Gong JG, Gutierrez CG and Armstrong DG (1999) Molecular mechanisms regulating follicular recruitment and selection Journal of Reproduction and Fertility Supplement 54 33-48

Received 8 June 2001

First decision 26 July 2001.

Accepted 4 September 2001. 